\title{
РЕЛИГИЯ В ТВОРЧЕСТВЕ СУХРАБА СИПЕХРИ
}

\author{
к.ф.н. Шоалиева Наргиза \\ Международная исламская академия Узбекистана, кафедра «Классическая восточная \\ литература и источниковедение»
}

DOI: https://doi.org/10.31435/rsglobal_ws/31102019/6732

\section{ARTICLE INFO}

Received: 11 August 2019

Accepted: 15 October 2019

Published: 31 October 2019

\section{KEYWORDS}

Suhrab Sipehri, religion, faith, spiritually, poem, symbol, mystic, love, being, classics, literature.

\begin{abstract}
Relation to religion and religious values in the poetry of Suhrab Sipehri, occupies a special place among the spiritual values of the poet. Being an inextricable part of Sipehri's worldview, this attitude can be called the main idea of his creative heritage, which acts as a kind of harmony between the poet's society, being and "I". In particular, the concept of the essence of religion and being as the main means of expression is manifested to a greater or lesser extent in almost all verses of Suhrab Sipehri.

According to Sipehri, religion and faith are a spiritual tool that can satisfy a person's moral needs. It cannot be imposed or imposed on anyone by force. Faith should not come from outside, but from the person himself, from his moral and spiritual needs, otherwise it will not turn into a means of improving a person, or ennoblement of him, but as a means restricting human freedom.
\end{abstract}

Citation: Шоалиева Наргиза. (2019) Religiya v Tvorchestve Suhraba Sipekhri. World Science. 10(50), Vol.2. doi: 10.31435/rsglobal_ws/31102019/6732

Copyright: (C) 2019 Шоалиева Наргиза. This is an open-access article distributed under the terms of the Creative Commons Attribution License (CC BY). The use, distribution or reproduction in other forums is permitted, provided the original author(s) or licensor are credited and that the original publication in this journal is cited, in accordance with accepted academic practice. No use, distribution or reproduction is permitted which does not comply with these terms.

Отношение к религии и религиозным ценностям в поэзии Сухраба Сипехри, занимает особое место среди духовных ценностей поэта. Являясь неразрывной частью мировоззрения Сипехри, это отношение можно назвать главной идеей его творческого наследия, которая выступает своеобразной гармонией между обществом, бытием и «я» поэта. В частности, понятие сути религии и бытия как главного средства выражения, проявляется в большей или меньшей степени практически во всех стихах Сухраба Сипехри. Первое обращение поэта к этой теме начинается в сборнике آوار آفتاب «Крупинки солнца». Этот сборник, который был издан в 1961 году, свидетельствует о начале формирования светского мировоззрения поэта. Говоря иначе, именно с этого момента начинаются серьезные размышления поэта над такими философским проблемами как поиск путей постижения человека и цели его жизни, внутреннего мира человека, его желаний и надежд, понимание Бытия и Создателя, познание бытия и познание Бога. Сухраб Сипехри достиг этапа, когда воспринимаешь мир другими глазами, или как говорит сам поэт «видеть друга сквозь дождь» ${ }^{1}$. Эта духовная революция, которая поднялась во внутреннем мире поэта в итоге призвала его скитаться по миру и изучать различные религии ${ }^{2}$. Религия по трактовке Сухраба Сипехри, это не только сборник, состоящий из законных предписаний, а первооснова, которая обладает силой способной поднять человека, до уровня Совершенного Человека.

По мнению Сипехри, религия и вера - это духовное средство, способное удовлетворить моральные потребности человека. Ее нельзя навязать или насаждать кому-то силой. Вера должна исходить не извне, а от самого человека, от его морально-духовных потребностей, в противном случае она превратится не в средство совершенствования человека, или облагораживания его, а в средство ограничивающее свободу человека. Это неизбежно приведет к тому, что религия станет всего лишь искусственным и пустым местом.

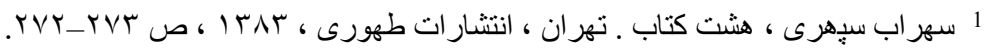

2 Мухаммад Хукуки. Сухроб Сипехри, Тегеран, 1992. С. 58. 
Сухраб Сипехри очень чутко и глубоко понимает религию, однако не считает себя ни религиозным деятелем, ни поэтом в религиозной оболочке. Прежде всего, он искатель вечной истины в людской жизни, и вообще суть жизни, деятель, находящийся в творческом поиске, бдительный человек, который старается сохранить сердце и свое «я» в противоречивости отношений между временем, общественными и политическими процессами и простым человеком. Сипехри созерцает все сущее, события и явления бытия через призму своего сердца, он поэт, жаждущий красоты, прежде всего гармонии мира и людского совершенства. Однако, вышесказанное не означает, что Сухраб Сипехри воспринимает все впечатления внешнего мира, через свой внутренний мир, через свою душу, и его стихи всего лишь плод наблюдений поэта. Он не только поэт, наделенный даром чувственного восприятия внешнего мира, но и ученый, поэт философ который воспевает события и явления благодаря логическому мышлению. Большинство стихов Сухраба Сипехри - это философские мысли в художественном облачении. Точнее, стихи для Сипехри, служат для выражения его философских мыслей в форме модернизированного искусства. Поэтому, он подвергая художественному анализу существующее или должное отношение человека к религии, критикует общество замкнутое в религиозный фанатизм, призывая его посмотреть на мир с новым мышлением.

Религиозное мировоззрение С.Сипехри сформировалось на основе учений ислама. Он родился и вырос в среде, где доминировал ислам, в этой же среде он воспитывался, и воспринимал себя как поэт-мусульманин. Однако, по убеждению поэта, мусульманство выходит за границы религиозных идей и трактуется как общечеловеческие ценности. Поэт ставит вопрос ребром «кто такой мусульманин?», и ищет ответ на него в свойственной ему манере. Вот как об этом пишет сам поэт в поэме صداى باى آب «Звуки журчанья воды»:

Я мусульманин.

Мой алтарь - красный цветок.

Молитвенньй коврик-родник, мой мухр - свет.

Степь - моя святыня.

Я очищаюсь дрожаньем окон.

В моей молитве пльвет месяи, переливается радуга.

За молитвы появляется камень.

Все частички моей молитвы превратились в хрусталь.

Я читаю молитву на макушке кипариса

Там, где ветер сочинил свой «азан»,

Я молюсь, в «храме воспевания» трав,

В следах стана волн.

Герой-лирик, которого описывает С. Сипехри, мусульманин, он также как и другие мусульмане совершает омовение, читает намаз, для него существуют такие святые понятия как «молитвенный коврик», «мухр», он также как и все, услышав азан спешит на молитву... Его молитва протекает в объятьях абсолютно чистых, прозрачных и прекрасных чувств. С.Сипехри передает состояние своего героя-лирика, через ощущения мусульманина во время молитвы, связывая их с самыми обычными, естественными, прекрасными и чистыми пейзажами и элементами природы, как «мак-красный цветок», «родник», «степь», «месяц», «камень», «ветер», «кипарис», «трава», «волна». Это описание, раскрывает всю динамику процесса перемен, происходящих в духовно-нравственном состоянии его героя-лирика, мусульманина: герой, который отдается молитве всем своим существом, превращается в единое целое с природой и вселенной, он перемешивается с пейзажами и элементами природы, а природа смешивается с ним, в результате появляется цельность и единство. С этой точки зрения, религия - это сама жизнь, религия и бытие, то есть природа в творчестве поэта, переплетаются друг с другом, и дополняя друг друга, создают единое целое.

С. Сипехри приемлет именно такую форму преклонения. Так как только в таком состоянии экстаза, человек очищается, получая от молитвы наслаждение, безмятежность и душевное спокойствие. Если с одной стороны герой - лирик С. Сипехри представляется как обычный мусульманин, то с другой стороны он проявляется как просвещенный мусульманин. То есть он личность, наделенная простотой и искренностью, просвещением и индивидуальностью. В этом

\footnotetext{
${ }^{1}$ Камень который ставят на коврик во время молитвы (у шиитов)

2 «азан» - призыв на молитву
} 
отношении богослужение для обычного мусульманина, является очищением и средством покаяния в грехах, и в то же время, просвещенный человек, становится средством для его единения с Аллахом.

По трактовке Сипехри, если религия и молитвы не будут призывать человека к осознанию того, насколько он близок к всевышниму, то они превратятся в обычную каждодневную рутину и потеряют свой истинный смысл. Эту мысль поэт выражает следующим образом:

Было бытие, и напев

Были губы и молитва.

Был «Я» и только «Тыл» была:

Была молитва и только алтарь.

$$
\text { (بАлтарь»)1. }
$$

По мнению Сипехри, появление единой гармонии посредством отождествления «бытия» с «мелодией», «губ» с молитвой, «Я» (человека, частицы) с «Ты» (богом, высшей субстанции), формирование единства или целостности «молитвы» с «алтарем», и есть итог истинного поклонения перед богом.

Герой-лирик С. Сипехри свободомыслящий мусульманин. Он желает чтобы все было в свой час и на своем месте. По его мнению, молитва должна быть в свой час, учеба в свое время и наслаждение красотой в свой срок.

Сердие мое заволокло как тучи

Смотрю в окно, вижу Гурию

-Совершеннолетнюю дочь соседа-

Около самой редкой вязи в мире,

Читает мусульманские законы.

( نداى آغاز ندо начала»)².

С точки зрения Сипехри, мусульманское право, законы ислама обременительны не только для дочери соседа - Гурии, достигшей совершеннолетия, но вообще тяжелая ноша:

Я видел поезд, он перевозил фикх ${ }^{3}$

И тяжело передвигался.

(«Звуки журчанья воды») $)^{4}$.

Чтобы передать тяжесть этого «груза», поэт прибегает к описанию «грузового поезда». Однако и это не цель. Цель - констатация факта появления религиозно-политических сил, намеревающихся превратить религию в формальный, поверхностный обычай, и даже в политику. Именно поэтому, он логически развивая описание «поезда, который тяжело передвигается перевозя законы», создает новый парадокс:

Я видел поезд, он перевозил политику

(и как легко он ехал).

(پВвуки журчанья воды»)

Поезд, который еле передвигается от тяжести исламского права, законов шариата, в то же время совершенно пуст. Так как он перевозит политику. А политические революции, которые противоречат естественному развитию общества, никому не принесут счастья. В свою очередь, Сипехри, не поддерживает никакую революцию, так как все революции, проходят через улицы кровопролитий. И наконец Сипехри, ученый - поэт, который выступает против любого кровопролития.

В этой связи, поэта постоянно интересует актуальная проблема - какое место у религии в ее отношениях с современным прогрессом, и какова ее позиция в отношениях среди новых обществ. Поэт ищет ответ на этот вопрос. И его ответ проявляется в идее - религия - для души. Поэт осуждает использование религии в политических играх.

Сипехри поддерживая идею ученого Икбала Лахури - «поэзия тоже пророчество», вместо «пророчества» применяет свои образы - «вода», «ум», «свет», отображающие просветительские идеи поэта:

Поэтыл

наследники воды, ума и света.

\footnotetext{
${ }^{3}$ мусульманские законы
}

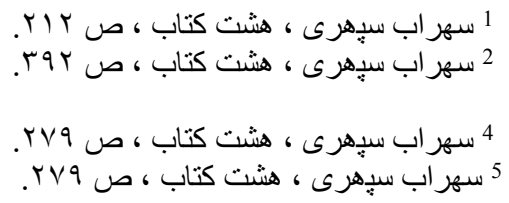




$$
\text { («За морями») })^{1} .
$$

Эти символические образы, которые очень часто встречаются в стихах Сипехри, свидетельствуют о том, что душа поэта вдохновляется этими тремя источниками - «вода», «ум» и «свет». На самом деле сама жизнь также продолжается благодаря этим трем элементам. Эти три составляющие, логически связаны друг с другом: вода - это тот же свет, ум - это форма света в человеческом сознании. Только свет может приблизить человека к счастью, к истине.

В этом отношении, «вдохновение» поэтов, рассматривается как «божественное откровение», посланное всевышним. С. Сипехри возвышает бремя ответственности слов и мыслей, заполняющие его сердце в форме вдохновения и под этим впечатлением, поднимается до уровня пророка, который доносит до людей предписания нового «шариата». Одним из примеров стихотворений, написанных в этом духе, является صور هء تاماثنا «Сура зрелища».

Клянусь зрелищзем

И началом слова

И полетом голубя из сознания

Слова заточили в клетку².

Сипехри, который был противником всему что разделяет и препятствует милосердию и любви среди людей, доброте и сочувствию, начинает символическую «суру» своего «зрелища», переиначив первый стих «Библии» - «В начале было слово», как «начало слова». Следовательно, «начало слова» - следует понимать как, «Во имя аллаха милостивого и милосердного». То есть, С.Сипехри, клянясь «Аллахом милостивым и милосердным», стремится убедить людей в том, что «слово заточили в клетку», или, иначе говоря, что у него в душе есть много слов, которые он не может произнести. Это состояние напоминает ощущения поэта, который задыхается от впечатления божественного света, проникающего во время его вдохновения.

В продолжении этого стихотворения, включенного в сборник حجز вместилище», герой-лирик поэта, поводырь, объясняющий людям свое новое учение, обращается к обществу, которое ищет путь к истине, на языке символов и лозунгов:

На ладони земли, есть редкий жемчуг,

Уставились взгляды пророков на сияние его.

Ииите этот жемчуг.

Доставьте мгновенья до пастбища пророчества.

И я им,

Предскажу звуки шагов посланника,

И близость дня, и буйство красок.

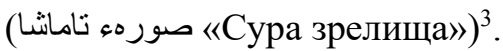

С. Сипехри с одинаковым уважением относится ко всем религиозным учениям. Он верит только в самые чистые чувства во всех религиях и религиозных учениях, высоко оценивая только эти стороны религии. Словом, по мнению поэта, религия - путь очищения и духовного возвышения человека.

Сипехри, в рамках философско-правовых воззрений, отказывается от изложения прошедших или происходящих событий, случаев и явлений, и переходит к описанию происшествий, которые должны случиться. Он старается объяснить людям, что нужно сделать для достижения настоящего счастья, втолковать какой путь надо выбирать:

Я был под ивой.

Сорвал листок над своею головою.

Откройте глаза, хотите аят ${ }^{4}$, лучше, чем этот?

Я сльишал, как они перешептывались:

Колдовство знают! колдовство ${ }^{5}$.

В этом стихотворении Сипехри не претендует на пророчество. Напротив, приводя в доказательство дары всевышнего и его пророка, через описание наставления своего рода на путь истинный и того, как люди в страхе клевещут на него «колдовство», подтверждает, что он

\footnotetext{
${ }^{4}$ Суры состоят из аятов
} 
верит в Аллаха и его посланника. Далее в стихотворении есть понятия, которые напоминают божественное откровение: «Мы послали ветры, чтобы они унесли шапки с их голов» ${ }^{1}$.

Большое влияние на С.Сипехри оказала поэзия Джалалиддина Руми, которая полна просветительскими идеями. Сипехри подражает поэзии Руми в смысловом и содержательном плане. Особенно, это можно наблюдать в строках Руми, который говорит: «Я вместе $c$ семидесятью тремя религиями» и призывает, одинаково относится к огнепоклонникам, христианам, иудеям, мусульманам. В свою очередь познания буддизма не обошлось без отражении в его поэзии строки Сипехри - «Над головой моей Коран, моя подушка Библия, мой матраи - Тора, моя майка - Авеста. Вижу сон: в лилии на воде - Будда», ${ }^{2}$ призывают в равной степени изучать все религиозные учения. Можно сказать, С.Сипехри превращая идею «межрелигиозного согласия» и толерантности в основную тему своего творчества, возвышает понятие «человек» над понятием «религия», трактуя «религию» как неразрывную часть моральных человеческих ценностей.

С. Сипехри мыслитель, который имеет своего «тарыката» по отношении сущности этого бытья. И он начинает на первый взгляд с элементарных элементов как любовь к природе, потрагивая каждый деталь от песка до небес, но если углубляться над этими утонченностями поэта передается философическая мышления поэта который источником являются знания, познания бога, мистика, в другом новом виде касающейся только Сухраба Сипехри что можно называть неосуфизмом в новой поэзии Ирана и которые отличаются от М.Халлажа или других классиков. В духовного достижении «фана», Сипехри не видит «фана» конец достижения или соединения, а наоборот, у него все начинается заново в новом этапе, что дает понять Всевышний везде и всегда в движении и не стоит в одном месте. И отсюда начинаются его натурфилософческое мышление «видеть друга сквозь дождь», что он утопить всю бытье в «любовь».

Таким образом, отношения человека, религии и бытия в творчестве С.Сипехри, являются результатом общественных перемен, реформ и прогресса, произошедших в Иране во второй половине XX века, которые были связаны со сложным «исламским ренессансом» и «исламским модернизмом».

Из вышесказанного следует, по мнению С. Сипехри, религия - это «истина» и путь истинный, она, является важным моральным источником для человека. Это сила, которая направляет заблудших людей, на «правильный путь». Она не заурядный обычай, не просто нравы и традиции, а глубокий и прочный корень дерева жизни.

237 سهر اب سبهرى ، هشت كتاب ، ص 2 